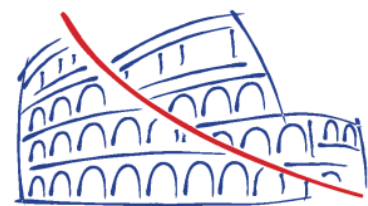

TIHE SECOND WORLD LANDSLIDE FORUM
Attilio Sulli ${ }^{(1)}$, Mauro Agate ${ }^{(1)}$, Claudio Lo lacono ${ }^{(2)}$, Valeria Lo Presti ${ }^{(1)}$, Valentina Pennino $^{(1)}$, Sabrina Polizzi ${ }^{(1)}$

\section{Submarine Slope Failures along the Northern Sicilian Continental Margin (Southern Tyrrhenian Sea) and Possible Implications for Geo-hazard}

(1) Università di Palermo, Dipartimento di Scienze della Terra e del Mare, via Archirafi 22, Palermo, Italy, attsu@unipa.it, +3909123864631

(2) CSIC, Unidad de Tecnología Marina, Paseo Maritimo de la Barceloneta 37-49, Barcelona, Spain

\begin{abstract}
In this study we present an overview of the mass wasting features (e.g.: submarine canyons, landslides, debris flows) and downslope movements that have contributed to shape the northern Sicily continental margin (southern Tyrrhenian Sea) since the Late Quaternary. The study is based on Multibeam data and high-resolution seismic reflection profiles, which allowed to define the morphology and the stratigraphy of the mass transport deposits and related failures of the area. We distinguished slope failures related to different mechanisms. In the Palermo Gulf and in the eastern sector of the northern Sicily margin tectonic activity, fluid escaping and oversteepening triggered downslope turbiditic currents and concurrent up-slope retrogressive mass failures. In the Ustica offshore gravitational collapse of volcanic edifices is mainly linked to neotectonic activity and volcanism. These data allow us to understand geological features and processes which may represent a threat for coastal areas of the northern Sicily margin.
\end{abstract}

Keywords: Slope failures; swath bathymetry; geo-hazard; Southern Tyrrhenian

\section{Introduction}

Since the early stages of modern exploration of the ocean various-scale features due to seafloor instability were recognized typically at the shelf break, where slopes are steeper, and in areas of high sedimentation rates. Mass failures consist of the movement of a volume of generally consolidated material along a slipping surface and represent one of the main processes for long distance sediment transport along continental margins (Haflidason et al. 2004). Repeated events of mass movement can remove a significant amount of submarine slope sediment strongly affecting slope morphology (Canals et al. 2004).

The classification of Mulder and Cochonat (1996) divided the processes involving submarine failed deposits into slides or slumps, plastic flows and turbidity currents. They are distinguished on the base of their style of movement, the shape of their failure surfaces, and the architecture of the resulting deposit. Multiple retrogressive failures propagating upslope are among the most common types. Although major slope failures tend to lower the regional slope angle, failure scars result in locally over-steepened slopes that require further morphological evolution before stabilization. The present-day morphology provides insights into the cumulative effects of failures and post-failure processes.

The triggering mechanisms and the predisposing factors favouring mass wasting are still not totally understood, even if it's well known that the type and frequency of mass failure processes are controlled by the interplay of different elements. The mechanical behaviour of sediments and slope geometry exert key roles in failure development and also have a high impact on the mass movement transport mechanisms, which can occur either in a cohesive or disintegrative fashion (McAdoo et al. 200o).

Sediment overloading and slope oversteepening represent the most common predisposing factors, whereas tectonic and volcanic activity, gas and fluid escape (Greene et al. 2002) and slope undercutting (Baztan et al. 2005) are commonly invoked as the trigger for instabilities. Dynamic processes along continental shelves and earthquake shaking are also common processes that instigate seafloor failures. These processes decrease the shear strength of the sediment down to a failure threshold by increasing the interstitial fluid pore pressure. Moreover, earthquakes generate ground accelerations in addition to the gravitational force (Almagor and Wisenam 1977). These causes make slope failures in submarine environments a common process that occurs also on gently dipping slopes (Lewis 1971).

Recent studies carried out on the Hawaii, Canary and Marianne Islands edifices have revealed considerable variability in flank morphology of the submarine volcanoes, indicating that they are affected by tectonic lineaments, minor volcanic apparatus and a range of mass wasting processes. The latter range from debris avalanches (Siebert et al. 1987), to slumps, slide scars generated by small-scale sliding (Chiocci et al. 2008), and flows of volcanogenic sediment (Urgeles et al. 1997). Submarine slope failures represent an important hazard to the coastal community as well as the off-shore activities for exploitation of marine resources. Thus, the 
interpretation of the physical processes that regulate mass failures constitutes the basis for the assessment and monitoring of the geo-hazard potential in coastal regions.

Evidences from many regions all over the world demonstrated that submarine failures are capable of generating even destructive tsunamis (Ward 2001). Historical records report that Greece and southern Italy are the most affected regions in the Mediterranean, interested by many destructive events in the past, mainly related to tsunamigenic earthquakes and slides (Chiocci et al. 2008; Mazzanti and Bozzano 2011). Most of the major tsunami occurred along the Sicilian-Calabrian coasts. After various events occurred during the last 300 years along the northern Sicily coasts, the most destructive tsunami occurred in the Messina Strait owing to the 1908 earthquake and landslide (Billi et al. 20o8) while the more recent was generated at Stromboli in 2002, in the Aeolian Islands, by submarine and subaerial sliding of volcanic material (Chiocci et al. 2008).

In this paper, we analyse in details the seafloor morphology along the northern Sicily continental margin, located between the Tyrrhenian back-arc basin and the Sicilian chain (central Mediterranean). Evidences of several mass-movement types have arisen from swathbathymetry and high-resolution seismic collected along this active margin slope, affected by widespread volcanism and seismicity.

The aims of this study are: 1) to outline the morphology of the mass failure features mapped in the northern Sicily continental margin, 2) to describe the mass-movement types, run out distances and transport mechanisms, 3) to recognize the main geological processes that control the mass failure processes of the area and 4) to highlight their potential implications for the geo-hazard of the northern Sicily offshore.

Bathymetric data (MultiBeam Echo Sounder) and seismic reflection profiles used for this study were mainly collected during several cruises in the frame of marine geological mapping (CARG) and geohazard assessment (MAGIC) Italian projects.

\section{Geological setting}

The northern Sicily continental margin (Fig. 1) is located in the southern Tyrrhenian Sea, from the north Sicily continental shelf to the Marsili Abyssal Plain, in the transitional area between the Sicilian-Maghrebian chain to the south and the Tyrrhenian Basin to the north. This continental margin is composed of: (1) a narrow $(<8 \mathrm{~km})$ and moderately steep $\left(1^{\circ}-2^{\circ}\right)$ continental shelf, (2) a very steep $\left(7^{\circ}-8^{\circ}\right)$ upper continental slope ranging in depth from 150 to $1000 \mathrm{~m}$, (3) a flat intra-slope basin plain at a depth of $1500 \mathrm{~m}$, (4) a lower continental slope that is wider and gentler than the upper slope and (5) a bathyal plain from a depth of $3000 \mathrm{~m}$.

The opening of the southern Tyrrhenian back-arc basin led to the subsidence of the northern Sicilian margin since the Late Tortonian (Bacini Sedimentari
1980). During the Pleistocene, E-W- to NE-SW-trending normal faults exerted a control on the morphology of the present day shelf and coastal areas.

Along the margin, intra-slope basins, termed periTyrrhenian basins by Selli (1970), originated as a consequence of crustal thinning, compressional events and strike-slip faulting (Agate et al. 200o). The periTyrrhenian basins have been filled with Late Neogene to Quaternary evaporitic, hemipelagic, siliciclastic and volcaniclastic deposits, up to $1200 \mathrm{~m}$ thick (Bacini Sedimentari 1980).

Along the shelf and the upper slope regions, the Quaternary deposits consist of seawards dipping clastic and terrigenous deposits coming from the northern Sicilian margin (Pepe et al. 2003; Agate et al. 2005), whereas in the basinal areas hemipelagic sediments are found, locally intercalated with volcanoclastic sediments (Bacini Sedimentari 1980).

In the continental shelf, the Pleistocene deposits are truncated by an erosional surface formed during the last glacio-eustatic oscillation. Local uplift caused the systematic non-preservation of portions of the oldest sequences (Pepe et al. 2003). Prograding sedimentary wedges of coastal deposits formed during the Last Glacial Maximum (about $18 \mathrm{kA}$ ) are present along the shelf margin. The prograding wedges are absent where the heads of the canyons or failure scars have indented the outer shelf (Lo Iacono et al. 2011).

Tectonic activity persists today with the occurrence of shallow $(<25 \mathrm{~km})$ seismic events of low to moderate magnitude (max Md 5.6 on September 2002; www.ingv.it) along an E-W trending belt located northward of the study area (Fig. 1). The focal mechanisms related to the main seismic shocks are in agreement with a dominant NE-SW fault trend coupled with a NW-SE compressive offset direction (Agate et al. 2000; Giunta et al. 2009).

\section{Submarine survey}

The morphology of the area has been studied by means of MultiBeam Echo Sounder (MBES) data, acquired in three different oceanographic cruises in 2001, 2004 (CARG cruises) and 2009 (MaGIC cruise), by using both the Reson SeaBat 8111, with depth range of $35-800 \mathrm{~m}$, and the Reson SeaBat 8160, with depth range of 30-3,000 m.

Post-processing of MultiBeam data included the graphic removal of erroneous beams, noise filtering, processing of navigation data and correction for sound velocity. Once cleaned, gridding of the filtered soundings was carried out to obtain the final DTM, which provided high resolution $3 \mathrm{D}$ views of the sea-floor, shaded relief maps, slope maps and bathymetric cross sections.

Various sets of CHIRP and multi- and singlechannel seismic profiles provided high resolution to high penetration data of the Plio-Quaternary sedimentary succession. The seismic lines interpreted using seismic facies analysis, which allowed depositional units, characterized by different seismic attributes, to be 


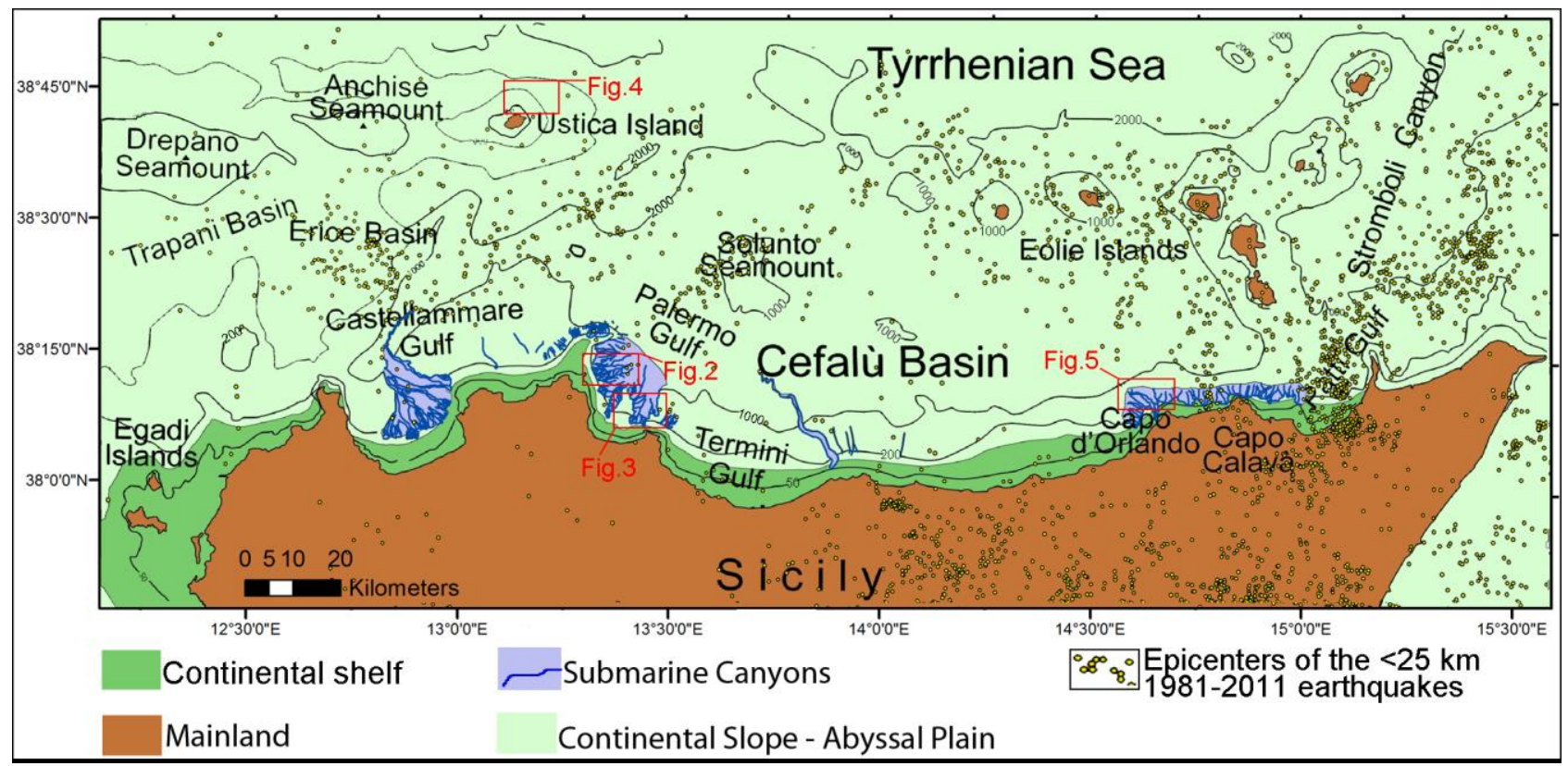

Fig. 1 - Simplified physiographic setting of northern Sicily offshore and distribution of epicentres related to the upper crustal seismic activity. Location of the studied instabilities is also shown.

distinguished.

Landslide volume was estimated by subtracting a pre-slide bathymetry from the actual bathymetry. The pre-slide bathymetric model was reconstructed by interpolating bathymetric nodes along the scar edges.

\section{Results}

Several examples of slope failures were analysed along the northern Sicily continental margin, whose morphological characters appear to be associated to different processes and related to a number of triggering and predisposing factors.

\section{The Palermo Gulf}

In the Palermo Gulf submarine canyon valleys deeply scour the upper slope or indent the shelf-edge, entering the Palermo intraslope basin at a depth of around $1,300 \mathrm{~m}$ (Lo Iacono et al. 2011). The canyons evolved through concurrent top-down turbiditic processes and bottom-up retrogressive mass failures. Most of the mass failure of the area are related to canyon shaping processes. Headward erosion processes are the main controlling factor in shaping the western sector of the Palermo Gulf, due to the occurring of a highly dissected substrate along the slope, which shows steep to very steep gradients that appear to favour a retrogressive evolution of the canyons. On the contrary, in the central-eastern sector, NNE trending canyons breaching the shelf break develop in connection with the Oreto and Eleuterio rivers that cross the coastal plain (Lo Iacono et al. 2011).

Many slope failures are present along the flanks of all the canyons. The only large slope failure feature that is not confined inside a canyon valley is the Priola Scar, along the western side of the Gulf (Fig. 2). The Priola scar displays a well preserved, semicircular shape with an upward concave failure plan; the headwall, that lies 3,5 $\mathrm{km}$ from the coastline at a depth of $145 \mathrm{~m}$, is about $900 \mathrm{~m}$ wide and $100 \mathrm{~m}$ high. The failure displacement surface extends as far as $3 \mathrm{~km}$ across the upper slope; it displays sharp slope breaks that highlight few secondary scars that can be up to $70 \mathrm{~m}$ high. Chaotic slide blocks, has been observed at a depth of about $475 \mathrm{~m}$. The Priola Slide is a complex slide made up of a slip plane with rotational displacement downslope evolving to a translation component. Total volume of the slide has been estimated to about $0.049 \mathrm{~km}^{3}$. No drapes by younger sediments have been imaged on high resolution seismic profiles, therefore we hypothesize a recent age of the failure. In

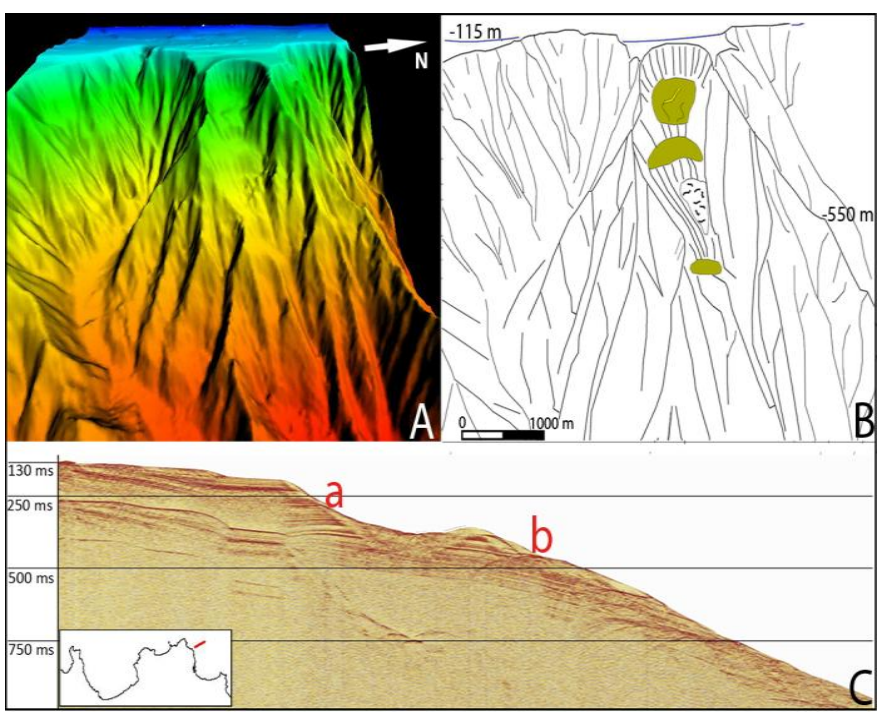

Fig. 2 - A) 3 D shaded relief model (vertical exaggeration is x3) derived from swath bathymetry data showing the Priola Scar. B) Interpretative drawing showing the slide scar and related landslide deposits. C) High resolution seismic profile imaging the Priola Scar truncating the Upper Quaternary deposits (a); chaotic facies on the right (b) corresponds to the slide deposits. 
this case slope oversteepening and the local tectonic setting appear to be the main predisposing factors.

The occurrence of pockmarks and small carbonate outcrops (illustrated in Lo Iacono et al. 2011) also suggests the probable role that fluid seeps play in the mass wasting processes of the area. A cluster of slides has been detected in the central sector of the Palermo Gulf (Fig. 3) where the continental shelf is wider (up to $4.750 \mathrm{~m}$ ) and the adjacent upper slope shows a lower gradient (about $3^{\circ}$ ) than others sectors in the Gulf. A train of pockmarks, on average $15 \mathrm{~m}$ deep, has also been detected in this area (Fig. 3) at a depth of $250-450 \mathrm{~m}$, with a diameter of $100-$ $250 \mathrm{~m}$. Failure scars occur just below the pockmarks, so we hypothesize a genetic link between the latter and slope failure features, as consequence of gas charging that reduces the sediment strength.
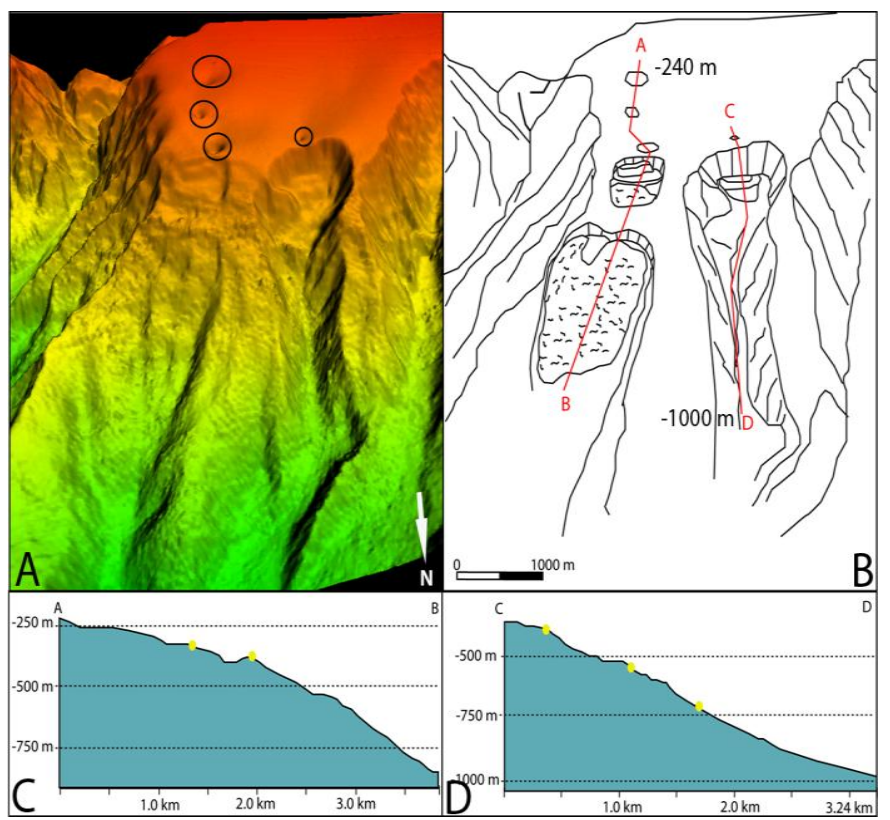

Fig. $3-$ A) 3 D shaded relief model (vertical exaggeration is $\mathrm{x} 3$ ) derived from swath bathymetry data showing the slide scars and the pockmark field in the southern sector of the Gulf of Palermo slope. B) Interpretative drawing of A where location of bathymetric profiles illustrated in C) and D) is

\section{The Ustica offshore}

Here we present an example of slope failure features in the volcanic edifices of the central Mediterranean coming from the NE offshore of Ustica Island, a Quaternary dormant volcano (Fig. 4), where a field of minor volcanic cones and mass wasting morphologies have been imaged during a recent bathymetric survey. Two kilometres far from the Ustica coastline, at a depth of $400 \mathrm{~m}$, two small volcanic cones up to $100 \mathrm{~m}$ wide, built inside and older crater, $550 \mathrm{~m}$ wide and $270 \mathrm{~m}$ high. The eastern flank of the older crater collapsed, probably during the build-up of the new cones. A chaotic mass transport about $14 \times 10^{-6}$ $\mathrm{km}^{3}$, lies $1.000 \mathrm{~m}$ south-eastward from the crater and accumulated inside a SW-NE trending structural depression, $700 \mathrm{~m}$ deep, bounded by others minor volcanic cones.

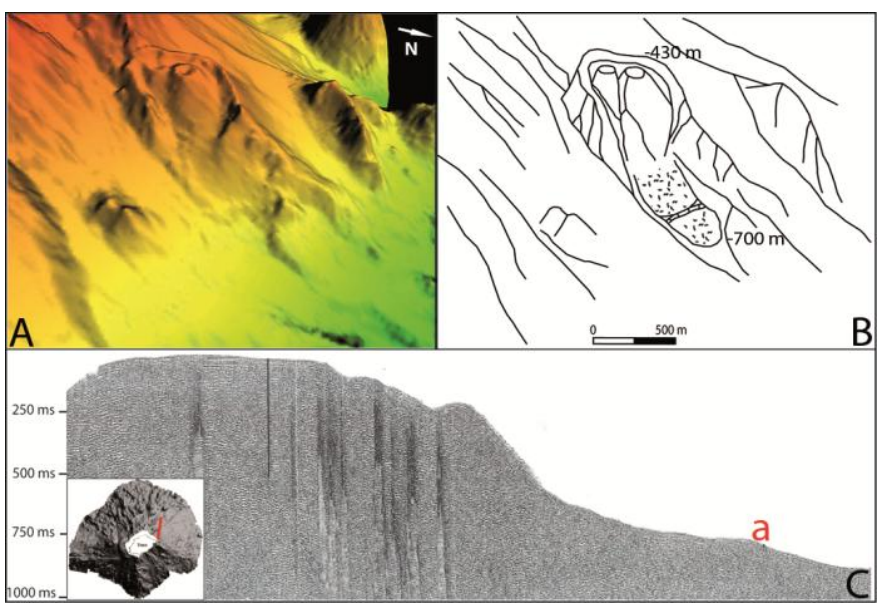

Fig. 4 - A) $3 \mathrm{D}$ shaded relief model (vertical exaggeration is x3) derived from swath bathymetry data showing the volcanic apparatus detected in the NE Ustica offshore. B) Interpretative drawing of slope failure and related landslide deposits; C) single channel seismic profile crossing the landslide deposits.

\section{The eastern sector of the northern Sicily margin}

Along the offshore sector between Capo d'Orlando and Capo Calavà (Fig. 1) an extensive network of submarine canyons (Fig. 5) scour a narrow continental shelf, no wider than $4.5 \mathrm{~km}$ up to a depth of $15 \mathrm{~m}$. Unlike the western sector of the northern Sicily margin, here the canyon heads are very close to the coastline, up to around $300 \mathrm{~m}$ in front of Capo Calavà, and form deep incised valley across the continental shelf. The flanks of these valleys host mass failure features.

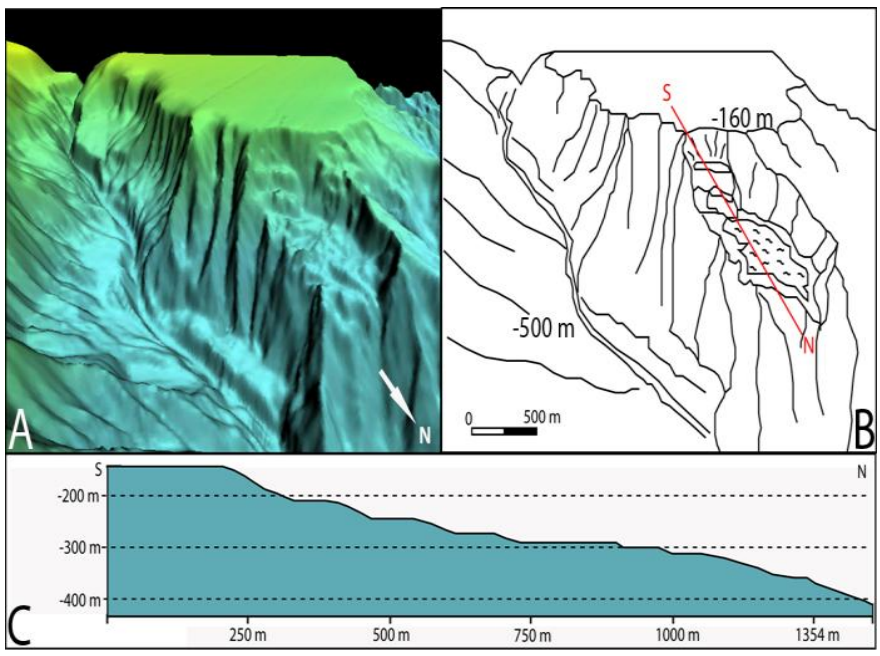

Fig. 5 - A) $3 \mathrm{D}$ shaded relief model (vertical exaggeration is x3) derived from swath bathymetry data showing the slide recognized along the western flank of the submarine canyon off Capo Calavà. B) Interpretative drawing of A where location of bathymetric profile illustrated in C) is shown. Note the staircase pattern of the seabottom profile and the hummocky seabed topography where chaotic slide deposits accumulated.

The largest submarine landslide of the northeastern Sicily offshore has been observed along the western flank of a canyon located west of Capo d'Orlando. The canyon headscarp is at a water depth of $18 \mathrm{~m}$ and is characterized 
by two small incisions that merge together in a major submarine channel, oriented along a N-S direction along the shelf and a SE-NW direction along the slope. Along the canyon, sediment instability induced the gravitational collapse of a sector of the western flank. The slide headwalls is $150-170 \mathrm{~m}$ deep and show a semi-circular shape. The collapsed deposits accumulated over a surface of $0.12 \mathrm{~km}^{2}$, at a depth of $350 \mathrm{~m}$. A few secondary scars have been observed producing a staircase bathymetric profile (Fig. 5). The landslide body consists of many, heterogeneous blocks accumulated in a chaotic pattern determining a typical hummocky sea floor surface. The slide is hanging $150-200 \mathrm{~m}$ above the canyon thalweg. Its total length is about $1 \mathrm{~km}$ and a total volume of $0.012 \mathrm{~km}^{3}$ has been estimated. Many others minor landslides are presents along the upper slope close to the major that has been here illustrated.

\section{Discussion}

Morphobathymetric and stratigraphic features suggest that a concurrence of processes contribute to the origin and the evolution of the slope failures in the northern Sicily continental margin.

The axial incision observed along the thalweg in most of the canyons demonstrates that active or recent downslope sedimentary fluxes occur along the slope (Baztan et al. 2005). Thus undercutting by turbidity currents and other erosive flows could have been responsible for gravity instability, contributing to the evolution of the submarine canyons.

In others cases sediment failures such as slumps, sliding or debris flows along the canyon walls suggest retrogressive mass failure events (Nelson and Maldonado 1988; Greene et al. 2002) that facilitate the upslope propagation of embryonic canyons towards the shelf margin (Mitchell 2005). So, shelf-indenting canyons may represent an evolutionary stage that is more mature than that of the juvenile canyons which are still confined to the slope. Once the landward migrating canyons indent the shelf-edge, they may intercept new sediment sources such as fluvial or along-shore transported sediments. During the evolution of the canyons, the retrogressive mass failures probably trigger turbidity currents, creating incisions along the thalweg. Axial incision would provoke undercutting, oversteepening and consequent instability of the canyon flanks, leading to further slumpings during a complex scenario of concurrent top-down and bottomup erosional mechanisms (Pratson and Coakley 1996).

In general, the mass failure features that occur on the canyon walls are relatively small and confined. They therefore do not pose a significant hazard to offshore infrastructures and do not constitute a possible threat of tsunamis along the coast (Driscoll et al. 200o). Nonetheless, some headscarps not confined to canyons could be potentially dangerous. Based on the morphometric analysis, the Priola Scar is the feature that deserves most attention. Mass failures with similar characteristics $\left(3.5 \mathrm{~km}\right.$ from the coast, $24-28 \times 10^{6} \mathrm{~m}^{3}, 150$ $\mathrm{m}$ depth) may constitute a potential of tsunami inundation at local scale (Dan et al. 2007).

Based on the available data, the main preconditioning geomorphological factor which could have induced sediment instability is the steep gradient of the slope. The average slope gradient of $20^{\circ}$ registered on the canyon walls and canyon heads may have favoured the occurrence of frequent mass failure events. The steep slopes of some of the canyon axes could have provoked a deep undercutting of the canyon heads and bring about headward migration by mass failure inside the narrow shelf. Most of the observed mass failure features were probably generated or were more active during the glacial periods when the coastline was closer to the slope and when the shelf margin constituted a shallow and more dynamic setting (Burger et al. 2003). The structural setting could also have contributed to the evolution of the submarine canyons and the mass failure processes. Some evidence of this control was found in the faults and folded structures.

Furthermore, the occurrence of pockmarks and highs that probably consist of authigenic carbonates above faulted and folded strata suggests a local relationship between structural control, fluid escape and mass failure. Some of the tectonic features could have represented a preferential escape route for fluids as evidenced by the pockmarks. Pockmarks may in turn trigger mass failures as evidenced by the headscarps observed below them. The structural features are possibly associated with the recent tectonics mapped on-land as well as the widespread seismicity of the margin.

Volcanic islands are the geological setting where submarine failures are very common as well as being among the largest slope failures on the seafloor. Impressive examples come from Hawaiian and Canary Islands (Masson et al. 1998; Urgeles et al. 1999).

In the Ustica offshore volcanism related features (gravitational collapse of volcanic edifices, debris avalanche and debris flows) are mainly linked to neotectonic activity and volcanism that tend to build, load and steepen the submarine slopes with time.

One important aim of future researches could be to ascertain whether these features are active and whether they pose a risk today. This would entail the identification of the main triggering mechanisms and the evaluation of the threat to coastal populations.

This study represents a first step in the understanding of those geological features and processes which may represent a threat for coastal areas of the northern Sicily margin. Further information, such as rate, recurrence period, released energy of the processes are necessary to evaluate the likelihood of occurrence to assess the geohazard of the study area related to mass failure. Future studies will become crucial to establish standard procedures for managing risks related to geological processes, considering also exposure and susceptibility (vulnerability) to losses. 


\section{Conclusions}

Morphobathymetric and seismostratigraphic data revealed the presence of mass failure features in the northern Sicily continental margin (Southern Mediterranean). The morphologies suggest that downslope turbiditic currents and concurrent up-slope retrogressive mass failures contribute to the shaping of the slope. Some canyons seem to be more controlled by turbiditic currents whereas the canyons of the steeper slopes are more dominated by retrogressive mass failure events.

The most prominent pre-conditioning factor in controlling the evolution of the mass failures is the steep gradient of the seafloor, especially along some sectors of the slope. The tectonic and volcanic setting of the area and punctual fluid escape processes may have contributed to slope instability.

In the light of our findings, most of the mass failures are small and enclosed in canyon systems, representing on the whole a low geo-hazard. The obtained results constitutes a reliable base for evaluating the geo-hazard potential related to slope failures in the area. Higher resolution morphobathymetric data, geotechnical test, monitoring of potential areas prone to mass failure and modelling landslides consequences along coastal areas would produce valuable informations for geohazard assessment and mitigation strategies.

\section{References}

Agate M, Beranzoli L, Braun T, Catalano R, Favali P, Frugoni F, Pepe F, Smriglio G, Sulli A, (2000) The 1998 offshore NW Sicily earthquakes in the tectonic framework of the southern border of the Tyrrhenian Sea. Mem. Soc. Geol. It. 55:103-114.

Agate M, Mancuso M, Lo Cicero G, (2005) Late Quaternary sedimentary evolution of the Castellammare Gulf (NorthWestern Sicily offshore). Boll. Soc. Geol. It.. 124:21-40.

Almagor G , Wisenam G H, (1977) Analysis of submarine slumping in the continental slope of the southern coast of Israël. Marine Geotech. 2:349-380.

Bacini Sedimentari (1980) Dati geologici preliminari sul bacino di Cefalu` (Mar Tirreno). Ateneo Parmense Acta Nat. 16:3-18.

Baztan J, Bernè S, Olivet J L, Rabineau M, Aslanian D, Gaudin M, Rehault J P, Canals M, (2005) Axial incision: the key to understand submarine canyon evolution (in the western Gulf of Lion). Mar. Petrol. Geol. 22:805-826.

Billi A, Funiciello R, Minelli L, Faccenna C, Neri G, Orecchio B, Presti $D,(2008)$ On the cause of the 1908 Messina tsunami, southern Italy. Geophys. Res. Lett. Doi:10.1029/2008GL033251.

Burger R L, Fulthorpe C S, Austin J A (2003) Effects of triple junction migration and glacioeustatic cyclicity on evolution of upper slope morphologies, offshore eel river basin, northern California. Mar. Geol. 199:307-336.

Canals M, Lastras G, Urgeles R, Casamor J L, Mienert J, Cattaneo A, De Batist M, Haflidason H, Imbo Y, Laberg J S, Locat J, Long D, Longva O, Masson DG, Sultan N, Trincardi F, Bryn P (2004) Slope failure dynamics and impacts from seafloor and shallow subseafloor geophysical data: case studies from the COSTA project. Mar. Geol. 213(1-4):9-72.

Chiocci, F L, Romagnoli C, Tommasi P, Bosman A, (2008) The Stromboli 2002 tsunamigenic submarine slide: Characteristics and possible failure mechanisms. J. Geophys. Res. 113, B10.

Dan G, Sultan N, Savoye B, (2007) The 1979 Nice harbor catastrophe revisited: trigger mechanism inferred from geotechnical measurements and numerical modelling. Mar. Geo. 245:40--64

Driscoll N W, Weissel J K, Goff J A (2000) Potential for large-scale submarine slope failure and tsunami generation along the US mid-Atlantic coast. Geology. 28:407-410.

Giunta G, Luzio D, Agosta F, Calò M, Di Trapani F, Giorgianni A, Oliveri E, Orioli S, Perniciaro M, Vitale M, Chiodi M, Adelfio G, (2009) An integrated approach to investigate the seismotectonics of northern Sicily and southern Tyrrhenian. Tectonophysics. 476:13-21.

Greene H G, Maher N M, Paull C K, (2002) Physiography of the Monterey bay national marine sanctuary and implications about continental margin development. Mar. Geol. 181:55-82.

Haflidason H, Sejrup H P, Nygard A, Mienert J, Bryn P, Lien R, Forsberg C F, Berg K, Masson D, (2004) The Storegga Slide: architecture, geometry and slide development Mar. Geol. 213: 201-234.

http://www.ingv.it. URL: http://cnt.rm.ingv.it/earthquakes_list.php

Lewis K B, (1971) Slumping on a continental slope inclined at $1^{\circ}-4^{\circ}$. Sedimentology. 16: 97-110.

Lo lacono C, Sulli A, Agate M, Lo Presti V, Pepe F, Catalano R, (2011) Submarine canyon morphologies in the Gulf of Palermo (Southern Tyrrhenian Sea) and possible implications for geohazard. Mar. Geophys. Res. DOI 10.1007/s11001-011-9118-0.

Masson D G, Canalis M, Alonso B, Urgeles R, Huhnerbach V, (1998) The Canary Debris Flow: source area, morphology and failure mechanism. Sedimentology. 45: 411-432.

Mazzanti P, Bozzano F,( 2011) Revisiting the February 6th 1783 Scilla (Calabria, Italy) landslide and tsunami by numerical simulation. Mar. Geophys. Res. DOI: 10.1007/s11001-011-9117-1.

McAdoo B, Pratson G, Orange L F, (2000) Submarine Landslide Geomorphology, U.S. Continental Slope. Mar. Geol. 169:103-136.

Mitchell N C, (2005) Interpreting long-profiles of canyons in the USA Atlantic continental slope. Mar. Geol. 214:75-99.

Mulder T, Cochonat P, (1996) Classification of offshore mass movements. J. Sediment. Res. 66: 43-57.

Nelson C H, Maldonado A, (1988) Factors controlling depositional patterns of Ebro turbidite systems, Mediterranean Sea. AAPG Bull. 72:698-716.

Pepe F, Sulli A, Agate M, Di Maio D, Kok A, Lo lacono C, Catalano R, (2003) Plio-Pleistocene geological evolution of the northern Sicily continental margin (southern Tyrrhenian Sea): new insights from high resolution, multi-electrode sparker profiles. Geo. Mar. Lett. 23:53-63.

Pratson L F, Coakley B J, (1996) A model for the headward erosion of submarine canyons induced by downslope-eroding sediment flows. GSA Bull. 108(2):225-234.

Selli R, (1970) Cenni morfologici generali sul Mar Tirreno. G. Geol. 37: 5-24.

Siebert L, Glicken H, Ui T, (1987) Volcanic hazards from Bezymiannyand Bandai-type eruptions. Bulletin of Volcanology. 49:435-459.

Urgeles R, Canals M, Baraza J, Alonso B, Masson D G, (1997) The most recent megaslides on the Canary Islands: the El Golfo Debris Avalanche and the Canary Debris Flow, west El Hierro Island. J. Geophys. Res. 102:20305-20323.

Urgeles R, Masson D G, Canals M, Watts A B, Le Bas T, (1999) Recurrent giant landslides on the west flank of La Palma, Canary Islands. J. Geophys. Res. 104: 25331-25348.

Ward S N, (2001) Landslide tsunami. J. Geophys. Res. 106: 1120111215. 